\title{
Editorial
}

\section{Número especial CIDI+CONGIC2019}

Este número especial da Infodesign apresenta trabalhos selecionados do conjunto de artigos apresentados no 90 Congresso Internacional de Design da Informação - CIDI 2019 e no 90 Congresso Nacional de Iniciação Científica em Design da Informação - CONGIC 2019, realizados na UniBH, em Belo Horizonte, de 11 a 14 de novembro de 2019.

Este número proporciona uma mostra da complexidade e responsabilidade do olhar do design da informação sobre alguns dos problemas atuais da sociedade. Aqui, os autores resgatam o humor, os sentidos, o discurso, a saúde, o aprendizado e nossa história. Além disso, os trabalhos de iniciação científica encontram seu espaço para falar com os consumidores, com os moradores das cidades, e sobre nosso patrimônio cultural.

Através da linguística cognitiva e a retórica visual, Lima revisa as metáforas visuais utilizadas por Nigel Homes. $\mathrm{O}$ autor entende que Holmes tende a sobrepor elementos pictóricos a elementos esquemáticos em seus gráficos estatísticos. Esta mescla de informação com elementos muitas vezes humorísticos é lida por Lima como uma abordagem que não se limita a uma suposta neutralidade da linguagem gráfica.

O entendimento da mídia como extensão do corpo e sentidos, defendido por Mcluhan, nunca foi tão atual como agora. Bosy e Portugal desafiaram artistas e designers a criarem vídeos como discurso e resposta a uma provocação. As autoras concluem que os vídeos criados podem ser lidos como uma extensão do físico e do ambiente numa linguagem compartilhada.

Perin, Chromiec e Beccari analisam o discurso do design da informação e identificam que alguns sistemas de análise são tomados como verdades atemporais e como base para novos sistemas .

Falkenburger e Scóz evidenciam a contribuição do design da informação na tomada de decisão dos consumidores na escolha de produtos alimentares. Os autores apresentam uma análise semiótica de três modelos de sistemas de selos nutricionais frontais adotados internacionalmente para advertir a população sobre a composição de determinados alimentos, e alertam que os três modelos analisados se restringem a apresentar traços particulares das composições sem de fato advertir. Cabe aos consumidores ter o conhecimento necessário para julgar se tais produtos são nocivos ou não.

Landim e Jorente consideram a carga cognitiva e o grau de literacia em saúde para apresentar um mapa conceitual com recomendações voltadas aos conteúdos textuais e gráficos para o design da informação de ambientes e-Saúde. 
Lima, Spinillo, Assis, Vital, Aquino e Oliveira verificam o principio da Teoria cognitiva do aprendizado multimídia nos aspectos gráficos informacionais das animações em saúde utilizadas em EaD

Aragão e Lima mergulharam na história de duas fundições tipográficas: a Funtimod - Fundição de Tipos Modernos, de São Paulo, e a Fundição de Typos Henrique Rosa, do Rio de Janeiro. Estas fundições fabricavam tipos móveis necessários para o funcionamento efetivo dos estabelecimentos gráficos até meados do século XX.

As autoras compararam os repertórios tipográficos das duas empresas e concluíram que tais repertórios estão relacionados com a época de início de seus trabalhos. Enquanto a Fundição de Henrique Rosa tinha uma variedade de tipos ornamentados criados no século 19, a Funtimod trabalhava com uma coleção mais coerente com a modernidade das primeiras décadas do século 20. Porém as autoras descobriram que a H. Rosa e Filhos também possuía alguns tipos modernistas, e que a Funtimod comprou parte do material do espolio da H. Rosa e Filhos. Essa pesquisa conjunta permitiu que esse elo histórico fosse revelado.

Amaral, Strey e Aguiar conversam com consumidores através do design da informação como lente analítica para relatar aspectos de sintaxe, ergonomia e signifier (affordance visual) de embalagens de alimentos de preparo rápido.

Já Conceição, Viana, Lima, Lócio e Almeida trazem o olhar do morador da cidade na forma de dingbats representativos da memória gráfica da cidade de Olinda.

Para facilitar a utilização de revistas capixabas encontradas nos três principais acervos públicos do Espírito Santo como fontes de coleta de dados, Matos, Santos, Nascimento e Fonseca propõem um método para inventariar quantitativamente e qualitativamente estas publicações.

Ainda no diálogo do design da informação com o patrimônio cultural, Oliveira e Farias revelam aspectos da cultura visual de São Paulo nos anos de 1857 a 1862 através do repertório de tipos empregados nos almanaques da Typographia Imparcial de Marques \& Irmão.

Uma boa leitura e parabéns a todos autores do CIDI+CONGIC2019.

Luciane Maria Fadel

Co-editora Infodesign

Infodesıgn | São Paulo | v. 16 | n. 3 [2019], 